\title{
Pelestarian Kudapan Kalua Kulit Jeruk Sebagai Warisan Gastronomi Sunda di Ciwidey Jawa Barat
}

\author{
Sofia Nuur Firmani ${ }^{1}$, Dewi Turgarini ${ }^{1}$, Mandradhitya Kusuma Putra ${ }^{2}$ \\ ${ }^{1}$ Manajemen Industri Katering, Fakultas Pendidikan Ilmu Pengetahuan Sosial, Universitas \\ Pendidikan Indonesia, Jl. Dr. Setiabudhi No. 229, Bandung 40154, Indonesia \\ ${ }^{2}$ Food and Beverage Service, Sekolah Tinggi Pariwisata Bandung, Jl. Dr. Setiabudi No.186, \\ Hegarmanah, Kec. Cidadap, Kota Bandung, Jawa Barat 40141
}

*Koresponding Penulis. E-mail: sofianuur@student.upi.edu (Sofia Nuur Firmani)

\begin{abstract}
Abstrak
Tujuan dari penelitian ini adalah untuk mengetahui sejarah, filosofi dan tradisi kalua kulit jeruk, serta untuk mengetahui bagaimana proses pembuatan kalua kulit jeruk dan menggambarkan kalua kulit jeruk dapat menjadi daya tarik wisata gastronomi sunda di Ciwidey, Jawa Barat . Jenis penelitian yang digunakan adalah kualitatif dengan metode wawancara mendalam, observasi dan dokumentasi. Populasi dalam penelitian ini adalah penghasil kalua kulit jeruk. Hasil penelitian ini menggambarkan sejarah awal penemuan kalua kulit jeruk, makna nama "kalua" dan tradisi yang terkait dengan kalua kulit jeruk dan menggambarkan proses pembuatan pemilihan awal bahan untuk proses penjualan dan melestarikan kalua kulit jeruk dengan membuat paket wisata gastronomi dan membuat kemasan untuk kalua kulit jeruk lebih menarik. Diharapkan dengan adanya beberapa upaya konservasi maka kalua kulit jeruk semakin diminati oleh masyarakat.
\end{abstract}

Kata Kunci: Kalua Kulit Jeruk; Gastronomi; Pelestarian; Daya Tarik Wisata

\section{Pendahuluan}

Negara Indonesia memiliki 34 Provinsi dengan beragam potensi wisata yang terdapat didalamnya. Karena itulah perkembangan pariwisata di Indonesia cukup pesat, karena berbagai potensi wisata yang dimiliki oleh provinsi-provinsi tersebut.

Kunjungan wisatawan mancanegara yang meningkat dari tahun ke tahun merupakan bukti perkrmbangan dari pariwisata di Indonesia.

Pariwisata itu sendiri adalah salah satu jenis industri baru yang mampu mempercepat pertumbuhan ekonomi dan penyedia lapangan kerja, peningkatan penghasilan standar hidup serta menstimulasi sektor-sektor produktif. Menurut Pendit (2003:33). Pariwisata merupakan aktifitas yang diperlukan oleh setiap individu dalam kehidupannya. Maka dari itu keadaan industri pariwisata saat ini menjadi penting dan dibutuhkan. Beragamnya jenis pariwisata saat ini membuat para wisatawan semakin mudah untuk memilih apa yang mereka inginkan, contohnya wisata bahari, wisata alam, wisata sejarah, wisata budaya, wisata pendidikan, wisata religi dan wisata gastronomi. Banyaknya pilihan wisata di Indonesia membuat industri pariwisata di negara Indonesia berkembang pesat.

Provinsi Jawa Barat menjadi salah satu provinsi pilihan para wisatawan untuk berwisata. Data dari BPS Provinsi Jawa Barat merilis perkembangan jumlah kunjungan jumlah wisata dar tahun 20122016, berikut data yang dihasilkan: 
Tabel 1. Jumlah Wisatawan Mancanegara dan Domestik di Provinsi Jawa Barat Tahun 2012-2016

\begin{tabular}{|c|r|r|r|}
\hline \multirow{2}{*}{ Tahun } & \multicolumn{2}{c}{ Wisatawan Visitor } & \multicolumn{1}{l|}{ Jumlah } \\
\hline 2012 & 1.905 .378 & 42.758 .063 & 44.663 .441 \\
\hline 2013 & 1.004 .301 & 45.536 .179 & 46.540 .480 \\
\hline 2014 & 1.962 .639 & 47.992 .088 & 49.954 .727 \\
\hline 2015 & 2.027 .629 & 56.334 .706 & 58.362 .335 \\
\hline 2016 & 4.428 .094 & 58.728 .666 & 63.156 .760 \\
\hline
\end{tabular}

Sumber : Badan Pusat Statistik Provinsi Jawa Barat, 2016
Data Tabel 1 menunjukan bahwa setiap tahunnya wisatawan domestik dan mancanegara ke Jawa Barat meningkat. Maka dari itu Jawa Barat terus mengembangkan potensi wisata yang ada untuk pemerataan wisatawan ke setiap kabupaten dan kota. Berikut merupakan data kunjungan wisata ke kabupaten dan kota di Jawa Barat.

Tabel 2. Jumlah Kunjungan Wisatawan menurut Kabupaten/Kota di Jawa Barat pada Tahun 2016

\begin{tabular}{|c|c|c|c|c|}
\hline No & $\begin{array}{c}\text { Kabupaten/ Kota } \\
\text { Regency/City }\end{array}$ & $\begin{array}{c}\text { Wisatawan } \\
\text { Mancanegara/ } \\
\text { Foreign Tourist }\end{array}$ & $\begin{array}{c}\text { Wisatawan Nusantara/ } \\
\text { Domestic Tourist }\end{array}$ & Jumlah/ Total \\
\hline \multicolumn{5}{|c|}{ KABUPATEN/ REGENCY } \\
\hline 1 & Bogor & 228913 & 4955079 & 5183992 \\
\hline 2 & Sukabumi & 49985 & 2031979 & 2081964 \\
\hline 3 & Cianjur & 12100 & 212096 & 224195 \\
\hline 4 & Bandung & 867000 & 5583468 & 6450468 \\
\hline 5 & Garut & 4983 & 671858 & 676841 \\
\hline 6 & Tasikmalaya & 1362 & 505570 & 506932 \\
\hline 7 & Ciamis & - & 126022 & 126022 \\
\hline 8 & Kuningan & 116 & 1189102 & 1189218 \\
\hline 9 & Cirebon & - & 664224 & 644224 \\
\hline 10 & Majalengka & 1500 & 443001 & 444502 \\
\hline 11 & Sumedang & 18637 & 992315 & 1010952 \\
\hline 12 & Indramayu & - & 111703 & 111703 \\
\hline 13 & Subang & 784972 & 3477300 & 4226272 \\
\hline 14 & Purwakarta & 2782 & 1957194 & 1959976 \\
\hline 15 & Karawang & 649 & 4574411 & 4575060 \\
\hline 16 & Bekasi & - & 49704 & 49740 \\
\hline 17 & Bandung Barat & 278027 & 1289657 & 1567684 \\
\hline 18 & $\begin{array}{l}\text { Pangandaran } \\
\text { KOTA/ CITY }\end{array}$ & 10344 & 1824367 & 1834711 \\
\hline 19 & Bogor & 13217 & 5293040 & 5305257 \\
\hline 20 & Sukabumi & 3266 & 82316 & 85582 \\
\hline 21 & Bandung & 432271 & 1431290 & 1863516 \\
\hline 22 & Cirebon & 1423 & 1354772 & 1356145 \\
\hline 23 & Bekasi & - & - & - \\
\hline 24 & Depok & 7812 & 1864273 & 1872085 \\
\hline 25 & Cimahi & 339 & 1968 & 2307 \\
\hline 26 & Tasikmalaya & 25 & 302908 & 302933 \\
\hline \multirow[t]{2}{*}{27} & Banjar & - & 50453 & 50453 \\
\hline & Jawa Barat & 2673379 & 39195668 & 43703778 \\
\hline
\end{tabular}

Sumber : Dinas Pariwisata Provinsi Jawa Barat 2016

Data pada Tabel 2 menunjukan Kabupaten Bandung menjadi daerah yang paling banyak dikunjungi oleh wisatawan lokal maupun mancanegara karena memiliki keindahan alam serta keuinikan budaya yang ada. Salah satu tempat popular yaitu
Ciwidey, wisatawan bisa menemukan beragam tempat wisata dan peninggalan nenek moyang yang masih ada hingga sekarang contohnya gastronomi sunda. Gastronomi adalah hal yang tidak bisa dipisahkan dari kehidupan. Semua orang 
memiliki hasratnya masing-masing bagaimana menikmati aneka makanan, minuman, dan produk lainnya sesuai dengan seleranya.

Menurut Taqwani (2012:55) Gastronomi merupakan studi mengenai hubungan antara budaya dan makanan, dimana gastronomi mempelajari mengenai komponen budaya makanan sebagai pusatnya yang berupa dengan budaya. Hubungan budaya dan gastronomi terbentuk karena gastronomi adalah produk budaya pada kegiatan pertanian sehingga warna, aroma, dan rasa dari suatu makanan dapat ditelusuri asalusulnya dari lingkungan tempat bahan bakunya dihasilkan.

Kalua kulit jeruk adalah salah satu kudapan warisan budaya gastronomi sunda di Ciwidey yang masih eksis sejak dulu hingga sekarang. Kudapan ini sangat unik karena bahan baku yang tidak lazim digunakan untuk panganan yaitu kulit jeruk bali bagian dalam yang masih mentah dan keras, dimasak dengan gula aren dan memiliki rasa yang manis berteksturempuk, karena keunikannya panganan ini masih banyak dicari oleh masyarakat. Kudapan Kalua kulit jeruk sendiri hanya bisa dijumpai di wilayah ciwidey dan sekitarnya, hal ini membuat masyarakat luar tidak begitu mengetahui adanya kudapan Kalua kulit jeruk. Karena kudapan ini tidak begitu banyak diketahui oleh masyarakan maka peneliti akan melakukan beberapa cara untuk melestarikan kudapan tersebut. Menurut A.W Widjaja (2010:2) pelestarian merupakan kegiatan yang dilakukan secara terus menerus, terarah dan terpadu guna mewujutkan tujuan tertentu yang mencerminkan adanya sesuatu yang tetap abadi, bersifat dinamis, luwes dan selektif.

Dengan adanya pelestarian yang dilakukan diharapkan kudapan ini akan terus bertahan dan bisa bersaing dengan kudapan lainnya yang ada di Ciwidey, maka dari itu penulis bermaksud melakukan penelitian mengenai "PELESTARIAN KUDAPAN KALUA KULIT JERUK SEBAGAI WARISAN GASTRONOMI SUNDA DI

\section{CIWIDEY JAWA BARAT.”}

\subsection{Rumusan Masalah Penelitian}

Adapun yang menjadi rumusan masalah dalam penelitian ini adalah sebagai berikut:

a. Bagaimana sejarah, tradisi dan filosofi kudapan Kalua kulit jeruk Gastronomi Sunda?

b. Bagaimana proses pembuatan kudapan Kalua kulit jeruk Gastronomi Sunda?

c. Bagaimana kalua kulit jeruk dapat menjadi daya tarik wisata Gastronomi Sunda di Ciwidey?

\subsection{Tujuan Penelitian}

Adapun tujuan dari penelitian ini dilakukan untuk memperoleh hasil sebagai berikut:

a. Mendeskripsikan filosofi kudapan Kalua kulit jeruk Gastronomi Sunda .

b. Mendeskripsikan proses pembuatan kudapan Kalua kulit jeruk Gastronomi Sunda.

c. Mendeskripsikan kalua kulit jeruk dapat menjadi daya tarik wisata Gastronomi Sunda di Ciwidey Jawa Barat.

\subsection{Manfaat Penelitian}

Manfaat penelitian ini dapat dibagi menjadi dua yaitu :

\subsubsection{Manfaat Akademisi}

Manfaat Akademisi ini dibagi menjadi dua yaitu

a. Secara Teoritis

Untuk mempertahankan Gastronomi Sunda yaitu Kalua kulit jeruk yang merupakan warisan makanan khas Ciwidey yang perlu dijaga tradisinya dan budaya nya karena makanan ini menjadi salah satu kudapan khas Jawa Barat, yang pada dasar nya penelitian ini dapat bermanfaat bagi keilmuan di Manajemen Industri Katering.

b. Secara Praktek

Penelitian ini dapat menambah ilmu dan pengalaman dalam melakukan 
penelitian dengan mengetahui perkembangan Gastronomi Sunda Ciwidey Jawa Barat, serta upaya pelestarian Kalua kulit jeruk sebagai kudapan khas Ciwidey Jawa Barat.

Penelitian ini juga dapat memberitahukan bagaimana cara pembuatan kudapan Kalua kulit jeruk serta sebagai sarana untuk meningkatkan kualitas Kalua kulit jeruk.

\subsubsection{Manfaat Keilmuan}

Manfaat keilmuan ini dibagi menjadi dua yaitu:

a. Membantu melestarikan kudapan Kalua kulit jeruk yang merupakan salah satu Gastronomi Sunda dan ikut serta menjaga kebudayaan yang dimiliki Ciwidey Jawa Barat.

b. Membantu dalam mendokumentasikan salah satu Gastronomi Sunda Indonesia dalam bentuk Karya Tulis Ilmiah (KTI).

c. Mengembangkan Kalua kulit jeruk sebagai daya tarik wisata Gastronomi Sunda di Ciwidey Jawa Barat.

\subsection{Pengertian Pariwisata}

Menurut Suwantoro (2004:5) pariwisata adalah istilah yang berhubungan erat dengan pengertian perjalanan wisata yaitu sebagai suatu perubahan tempat tinggal sementara seseorang dari tempat tinggal asalnya karena suatu alasan tertentu dan bukan untuk melakukan kegiatan yang mampu menghasilkan upah.

Menurut Pendit (2006:4) pariwisata akhir-akhir ini telah menjadi pokok pembicaraan dalam khalayak ramai. Banyaknya destinasi pariwisaata di Indonesia membuat Indonesia menjadi tujuan bagi para wisatawan domestic maupun internasional. Lebih ramai lagi setelah Bapak Presiden soeharto menyampaikan kata sambutan beliau dalam pertemuan ramah-tamah dengan para peserta seminar dan rapat kerja kepariwisataan 27 November 1982 di Istana Negara. Pada kesempatannya Bapak Presiden Soeharto menyampaikan RAPBN tahun 1982 masalah pariwisata merupakan salah satu masalah satu sector penting dalam meraih devisa lebih banyak lagi di dalam mengahadapi resesi dunia dewasa ini.

Menurut pengertian para ahli diatas dapat disimpulkan bahwa pariwisata adalah kegiatan perjalanan yang dilakukan untuk sementara ke berbagai tujuan wisata untuk kegiatan tertentu. Dan sector pariwisata mampun meraih devisa bagi perekonomian negara.

\subsection{Daya Tarik Wisata}

Daya Tarik Wisata sejatinya merupakan kata lain dari objek wisata namun sesuai peraturan pemerintah Indonesia tahun 2009 kata objek wisata sudah tidak relevan lagi untuk menyebutkan suatu daerah tujuan wisatawan maka digunakanlah kata " Daya Tarik Wisata" maka untuk mengetahui apa arti dan makna dari daya tarik wisata di bawah ini adalah beberapa definisi/pengertian mengenai DayaTarik Wisata menurut beberapa ahli :

a. Berdasarkan Undang-Undang Republik Indonesia No. 10 tahun 2009, Daya Tarik Wisata dijelaskan sebagai segala sesuatu yang memiliki keunikan, kemudahan, dan nilai yang berupa keanekaragaman kekayaan alam, budaya, dan hasil buatan manusia yang menjadi sasaran atau kunjungan wisatawan.

b. Menurut Spilanne (2002), Daya tarik pariwisata adalah hal - hal yang menarik perhatian wisatawan yang dimiliki oleh suatu daerah tujuan wisata.

Objek dan daya tarik wisata adalah suatu bentukan dan fasilitas yang berhubungan, yang dapat menarik minat wisatawan atau pengunjung untuk datang ke suatu daerah atau tempat tertentu. Daya tarik wisata yang tidak atau belum dapat disebut sebagai daya tarik wisata, sampai adanya suatu jenis pengembangan tertentu. Objek dan daya tarik wisata merupakan dasar bagi kepariwisataan. Tanpa adanya daya tarik di suatu daerah atau tempat tertentu, 
kepariwisataan sulit untuk dikembangakan.

\subsection{Wisata Budaya}

Kamus besar bahasa Indonesia berpendapat wisata budaya adalah kegiatan bepergian bersama-sama dengan tujuan mengenali hasil budaya di daerah setempat seperti peninggalan sejarah, museum atau atrasi kesenian. Sedangkan menurut R.S Damardji (1989:19) mengatakan bahwa wisata budaya adalah gerakan atau kegiatan wisata yang dirangsang oleh adanya objekobjek wisata yang berwujud hasil-hasil seni budaya setempat seperti adat istiadat, upacara agama, tata hidup masyarakat peninggalan sejarah, seni, kerajinankerajinan rakyat dan sebagainya. Tujuan dari wisata budaya adalah melestarikan alam, memajukan kebudayaan, mengangkat citra bangsa, memupuk cinta tanah air, memperkukuh jati diri bangsa serta mempererat persahabatan antar bangsa.

Wisata budaya ini memiliki unsurunsur yang menjadi daya tarik wisatawan, diantaranya :

a. Event pertunjukkan yang dikemas dari budaya atau adat istiadat masyarakat setempat

b. Riset dan penelitian ilmiah serta kegiatan lain yang bersifat edukatif kultural

c. Unsur-unsur yang bersifat tangible atau kebendaan yang berupa hasil kerajinan yang bercirikan kearifan budaya setempat

d. Unsur lain yang dikemas dalam event wisata sejarah dan wisata pendidikan

Namun wisata budaya ini memiliki efek negatif terhadap kelangsungan budaya itu sendiri, diantaranya :

a. Terjadinya interaksi masyarakat tradisional dengan masyarakat modern yang memungkinkan adanya pola saling mempengaruhi, yang akan merubah pola kehidupan budaya masyarakat setempat.

b. Komersialisasi wisata budaya yang berlebihan mengakibatkan adanya upaya untuk merubah kultur budaya apabila dinilai kurang memiliki nilai ekonomis.

c. Terjadinya transformasi dari aktifitas sosial ke arah produk dan perkenalan dengan bentuk ekonomi yang baru akan sedikit banyak mengubah tata nilai struktur dan kultur masyarakat.

Timbul Haryono (2013:2) dalam paparannya tentang berbagai makanan dan minuman masyarakat Jawa Kuna. Menyebutkan bahwa :

a. Makanan dan minuman adalah suatu karya budaya untuk mempertahankan hidup.

b. Penggalian terhadap keberadaan makanan dan minuman Jawa Kuna sangat diperlukan karena merupakan hasil local genius masa lalu

c. Kekayaan makanan dan minuman merupakan salah satu unsur budaya yang dapat dimanfaatkan dalam perkembangan kepariwisataan yang bersumber dari kekayaan alam nusantara.

\subsection{Gastronomi}

Menurut Taqwani (2012:55) Gastronomi adalah suatu studi mengenai hubungan antara budaya dan makanan, dimana gastronomi mempelajari berbagai komponen budaya dengan makanan sebagai pusatnya yang berhubungan dengan budaya. Gastronomi terbentuk karena gastronomi merupakan produk budidaya yang terjadi pada kegiatan pertanian sehingga menghasilkan warna, aroma, dan rasa dari suatu makanan yang dapat ditelusuri asalusulnya dari lingkungan tempat bahan baku yang dihasilkan.

Pendapat lain dikemukakan oleh Soeroso dan Susilo (2014:72) mengatakan bahwa gastronomi adalah salah satu element yang menggabungkan konsep baru warisan budaya dan wisata budaya, didorong oleh tren gaya hidup, keaslian perlindungan lingkungan, dan kebutuhan untuk memiliki pengalaman berkualitas tinggi. Wisatawan semakin menginginkan makanan yang menekankan warisan dan budaya suatu 
tempat, yang membantu pelestarian bentuk tradisional pertanian dan warisan budaya. kajian sangat interdisipliner yang berkaitan dengan refleksi dari sebuah sejarah dampak budaya dan susanan lingkungan mengenai "bagaimana (how), dimana (where), kapan (when) dan mengapa (why)" makanan dan minuman penting bagi masyarakat dan industry jasa makanan.

Menurut Turgarini (2014:2)

Gastronomi sebagai sumber daya wisata merupakan sebuah pengalaman saat menikmati makanan dan minuman yang unik kekuatan untuk memikat wisatawan seperti halnya museum, rekreasi dan belanja. Gastronomi sebagai sumber daya wisata, dihargai tidak hanya untuk kepentingan diri sendiri, tapi juga karena kemampuan untuk menghasilkan pembangunan pedesaan dalam meningkatkan pendapatan dan pekerjaan tenaga kerja lokal. Perkembangan gastronomi sebagai objek wisata diakui sebagai cara untuk melakukan budaya kuliner lokal, merangsang permintaan pariwisata, dan meningkatkan daya saing destinasi sehingga pariwisata gastronomi juga telah muncul sebagai komponen yang semakin penting. Wisatawan akan merasa mendapat pengalaman lebih kea rah budaya lokal, kemudian masyarakat berbagi budaya lokal mereka dengan wisatawan melalu media ini, penduduk setempat membuat representasi identitas tujuan. Pembentukan identitas dan penciptaan citra tepat berkaitan dengan makanan lokal, sehingga dapat menarik pasar yang dituju dan bermanfaat pengembangan pariwisata gastronomi.

\subsection{Kudapan}

Kudapan berasal dari kata "kudap" yang artinya jajanan atau makanan kecil. Fungsinya, untuk menghilangkan rasa lapar. Kamus besar bahasa Indonesia mengatakan bahwa kudapan adalah istilah bagi makanan yang bukan merupakan makanan utama ( makan pagi, makan siang, makan malam ) melainkan makanan kecil atau dalam bahasa inggris disebut juga snack. Makanan yang dianggap ringan merupakan makanan untuk menghilangkan rasa lapar seseorang sementara waktu, member sedikit pasokan tenaga ke tubuh atau sesuatau yang dimakan untuk dinikmati rasanya.

\section{Menurut Muaris}

menyebutkan bahwa kudapan atau snack adalah makanan yang sering disantap diluar waktu makan utama, bahkan sering juga disebut dengan makanan selingan. Bisa terjadi pada saat antara sarapan dan makan siang, antara makan siang dan malam atau dikenal juga dengan "hidapang sore hari untuk minum teh" atau bahkan setelah makan malam.

\subsection{Kalua Kulit Jeruk}

Kalua kulit jeruk merupakan makanan tradisional khas Ciwidey Jawa Barat yang memliki keunikan dari bahan baku yang digunakan yaitu kulit jeruk bali (citrus grandis) atau jeruk jambang bagian dalam yang berwarna putih yang masih mentah dan keras.

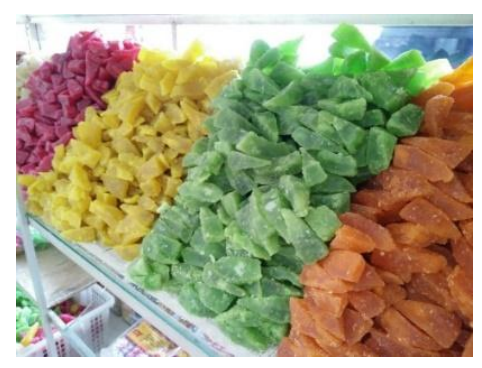

Gambar 1. Kudapan Kalua kulit jeruk

Bahan baku lainnya yaitu gula arena atau gula putih, kapur sirih dan pewarna makanan untuk membuat warna Kalua semakin menarik, rasanya manis dan sedikit kenyal, bentuknya lonjong seperti bulan sabit. Kalua memiliki dua jenis ada yang original memakai gula aren yang berwarna coklat dan yang berwarna memakai gula putih beserta pewarna makanan.

\subsection{Pelestarian}

Menurut Kamus Besar Bahasa Indonesia pelestarian berasal dari kata lestari yang artinya tetap selama lamanya tidak berubah. Penggunaan bahasa 
Indonesia penggunaan awalan pe- dan akhiran -an artinya digunakan untuk menggambarkan suatu proses atau upaya.

Menurut A.W Widjaja (2010:2) pelestarian merupakan kegiatan yang dilakukan secara terus menerus, terarah dan terpadu guna mewujutkan tujuan tertentu yang mencerminkan adanya sesuatu yang tetap abadi, bersifat dinamis, luwes dan selektif.

Menurut Chaedar (2006:18) pelestarian adalah sebuah upaya yang berdasar, dan dasar ini disebut juga faktorfaktor yang mendukung baik itu dari dalam maupun dari luar dari hal yang dilestarikan. Maka dari itu, sebuah proses atau tindakan pelestarian mengenal strategi ataupun teknik yang didasarkan pada kebutuhan dan kondisi masing-masing.

Menurut Karmadi (2007:25) Motivasi yang perlu dikembangkan untuk melaksanakan pelestarian antara lain adalah :

a. Motivasi untuk menjaga dan mempertahankan warisan budaya.

b. Motivasi untuk meningkatkan pengetahuan dan kecintaan generasi penerus bangsa terhadap nilai-nilai sejarah kepribadian bangsa dari masa ke masa melalui pewarisan khasanah budaya dan nilai-nilai budaya secara nyata.

c. Motivasi untuk menjamin terwujudnya keragaman atau variasi lingkungan budaya.

\subsection{Hipotesis}

Kalua kulit jeruk merupakan kudapan yang bisa ditemui di daerah Ciwidey Jawa Barat, sayangnya masyarakat yang berkunjung ke Ciwidey tidak banyak yang mengetahui keberadaan kudapan khas daerah tersebut. Kalua kulit jeruk sendiri terbuat dari bahan-banyak yang banyak mengandung zat-zat yang baik dikonsumsi oleh tubuh. Menurut para ahli, kulit jeruk mengandung Vitamin $\mathrm{C}$, gula aren mengandung kalori dan serat yang tinggi, gula pasir mengandung nutrisi, air mengandung mineral.

\section{Metode Penelitian}

Metode penelitian yang diambil merupakan metode penelitian kualitatif.

\subsection{Objek Penelitian}

Objek dari penelitian ini adalah Kalua Kulit Jeruk sebagai salah satu Kudapan tradisional khas Ciwidey Jawa barat dengan subjek penelitian adalah produsen pembuat makanan Kalua Kulit Jeruk yang berada di daerah Ciwidey Jawa Barat. Penelitian ini bertujuan untuk memperkenalkan kembali makanan Khas Ciwidey Jawa Barat yang sudah hampir sulit dicari oleh masyarakan dan menjadikan salah satu upaya pelestarian dari Kalua Kulit Jeruk.

\subsection{Subjek Penelitian}

Adapun yang menjadi subjek dalam penelitian ini adalah pemerintah daerah, para ahli dibidang gastronomi, produsen Kalua kulit jeruk serta masyarakat sekitar. Mereka dipilih karena dinilai menguasai serta memahami mengenai permasalahan yang diteliti.

Tabel 3. Subjek Penelitian

\begin{tabular}{l}
\hline \multicolumn{2}{c}{ Informan Pokok Informan Pendukung } \\
\hline Pemerintah Daerah \\
Ahli Gasyarakat Sekitar \\
Budayawan \\
Produsen Kalua kulit \\
jeruk \\
Sumber : Data diolah oleh peneliti (2018)
\end{tabular}

Berdasarkan Tabel 3 Maka subjek penelitian ini terdiri dari informan pokok dan informan pendukung. Informan pokok merupakan sumber utama yang dapat memberikan data untuk penelitian ini. Sedangkan informan pendukung merupakan orang-orang yang menerima penetahuan dari informan pokok yaitu masyarakat, selain itu informan pendukung juga dapat memperluas penelitian ini.

Populasi Sampel dalam penelitian ini adalah produsen Kalua kulit jeruk dan metodenya adalah metode Sensus. 


\subsection{Lokasi Penelitian}

Lokasi penelitian yang diambil oleh penelit di Kabupaten Bandung Desa Ciwidey Jawa Barat. Lokasi tersebut dipilih karena merupakan penghasil utama dari kudapan Kalua kulit jeruk.

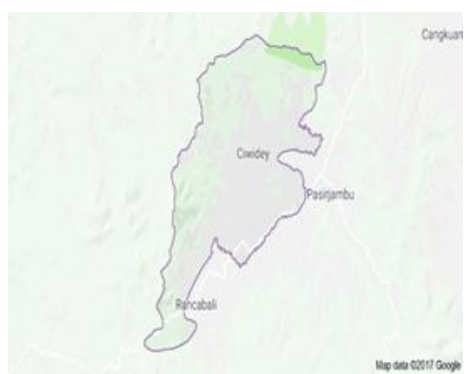

Gambar 2. Lokasi penelitian Ciwidey Jawa Barat

\subsection{Teknik Pengumpulan Data}

Teknik pengumpulan data pada penelitian merupakan hal utama dalam penelitian sebagai cara untuk memperoleh data dan membantu memecahkan masalah yang akan diteliti oleh peneliti. Teknik pengumpulan data dibagi menjadi beberapa bagian yaitu wawancara, observasi, dokumentasi dan studi literatur. Sesuai dengan bentuk pendekatan penelitian kuantitatif data yang akan digunakan untuk penelitian Kalua Kulit Jeruk Sebagai Warisan Gastronomi di Ciwidey Jawa Barat.

\subsubsection{Wawancara Mendalam}

Penulis mencari narasumber yang dianggap berkompeten untuk memberikan informasi yang dibutuhkan mengenai penelitian Kalua kulit jeruk. Peneliti melakukan wawancara dengan berbagai pihak diantaranya:

a. Pemerintah daerah

b. Para ahli Gastronomi atau budayawan

c. Produsen pembuat Kalua kulit jeruk

d. Masyarakat

Teknik wawancara yang dipilih adalah wawancara terstruktur dimana daftar pertanyaan yang diajukan oleh telah direncanakan dan disusun sebelumnya.

\subsubsection{Observasi}

Penulis melakukan observasi dengan mengambil lokasi pengamatan di ciwidey Kabupaten Bandung untuk mengetahui berapa banyak produsen Kalua kulit jeruk yang masih aktif memproduksi Kalua kulit jeruk. Observasi dapat dikaitkan dengan upaya merumuskan masalah, membandingkan masalah yang dirumuskan dengan kenyataan di lapangan. Teknik observasi merupakan salah satu teknik pengumpulan data dengan cara mencatat segala peristiwa ataupun fenomena mengenai objek yang diteliti yaitu kudapan Kalua kulit jeruk.

\subsubsection{Dokumentasi}

Dokumentasi yang dilakukan oleh peneliti dalam penelitian ini adalah:

a. Rekapitulasi data- data kunjungan wisatawan

b. Data peta lokasi penelitian

c. Foto wawancara dengan para narasumber

d. Foto produk kalua dari berbagai produsen serta alat-alat yang digunakan untuk membuat Kalua kulit jeruk

\subsubsection{Studi Literatur}

Dalam hal ini peneliti menggunakan studi literatur sebagai bahan dari metode penelitian yaitu dengan menganbil beberapa sumber buku yang ada baik untuk metode penelitian maupun berbagai sumber dari halhal yang menyangkut dengan penelitian tersebut misalnya seperti tentang gastronomi, kuliner nusantara, pelestarian hingga perkrmbangan kuliner di Indonesia pada saat ini. Selain dari buku peneliti juga menggambil beberapa referensi dari jurnal maupun laporan penelitian terdahulu yang berhubungan dengan pelestarian dan gastronomi nusantara.

\subsection{Analisis Data}

Penelitian harus memperhatikan tiga hal agar penelitian yang dilakukan mendapatkan data yang akurat secara ilmiah ketiga hal tersebut diantaranya regulasi data, penajian data, penarikan kesimpulan. 


\subsubsection{Reduksi Data}

Reduksi data merupakan salah satu cara yang dilakukan untuk merangkum , memilih hal-hal yang pokok, menginformasikan pada hal-hal yang penting, dicari tema dan polanya serta membuang yang tidak perlu. Sehingga dapat memberikan gambaran yang jelas dalam penelitian. Dalam hal ini peneliti mereduksi data dengan cara sebagai berikut :

a. Menggolongkan jawaban satu dengan jawaban lainnya yang dianggap sama dalam wawancara yang dilakukan sebelumnya

b. Selanjutnya setelah digolongkan, peneliti menghitung jawaban yang mana yang lebih banyak jawabannya.

c. Setelah mengetahui banyaknya jawaban yang dominan, peneliti mereduksi atau merangkum untuk memperoleh kesimpulan-kesimpulan yang dapat ditarik dan diverifikasi.

Data yang direduksi merupakan data hasil wawancara yang dilakukan kepada sumber-sember penelitian.

\subsubsection{Penyajian Data}

Penelitian kualitatif penyajian data bisanya dilakukan dalam bentuk uraian singkat, bagan, serta hubungan antar kategori. Menurut Sugiono (2016:341) adalah yang paling sering digunakan untuk menyajikan data dalam penelitian kualitatif adalah dengan teks yang bersifat naratif. Selain dalam bentuk naratif penyajian data juga bisa dilakukan dalam bentuk grafik, matrik, atau jejaring kerja.

\subsubsection{Kesimpulan}

Penarikan kesimpulan merupakan salah satu cara yang dilakukan agar penelitian yang dilakukan mendapatkan makna yang dianggap penting dari data yang telah diananlisis sebelumnya. Kesimpulan sendiri biasanya berupa data singkat, deskrispi atau gambaran objek yang diteliti seperti "Upaya Pelestarian Kalua Kulit Jeruk Sebagai Warisan Gastronomi di Ciwidey Jawa Barat" yang sebelumnya masih belum jelas sehingga setelah diteliti menjadi jelas.

\section{Hasil dan Pembahasan}

\subsection{Hasil Penelitian}

Hasil penelitian yang dipaparkan oleh peneliti merupakan hasil dari wawancara, observasi dan dokumentasi, sedangkan pembahasan merupakan hasil penelitian dengan menggunakan pandangan orisinlnya dalam sudut pandang kajian teoritis dan kasian empirik yang terdahulu.

\subsection{Hasil Wawancara}

Hasil dari penelitian ini merupakan wawancara yang dilakukan oleh peneliti kepada narasumber dari berbagai latar belakang yang berbeda seperti produsen Kalua kulit jeruk, pemerintah daerah, asosiasi serta praktisi.

Berikut merupakan biodata narasumber dan waktu pelaksanaan wawancara yang dilakukan penulis mulai dari tanggal 14 Maret 2018 sampai dengan 12 April 2018, untuk lebih jelas dapat dilihat pada Tabel berikut :

Tabel 4. Biodata Narasumber dan Waktu Pelaksanaan Wawancara

\begin{tabular}{|c|c|c|c|c|c|}
\hline No & Hari/Tanggal & $\begin{array}{c}\text { Nama } \\
\text { Lengkap }\end{array}$ & Usia & Pekerjaan & $\begin{array}{l}\text { Lembaga/ } \\
\text { Instansi }\end{array}$ \\
\hline 1 & $\begin{array}{l}\text { Jumat, } 23 \\
\text { Maret } 2018\end{array}$ & $\begin{array}{l}\text { Adi Ruhaendi, } \\
\text { SE }\end{array}$ & 56 Tahun & $\begin{array}{l}\text { Dosen dan } \\
\text { Ahli Gastronomi }\end{array}$ & $\begin{array}{ll}\text { Indonesia } & \text { Chef } \\
\text { Asossiason (ICA) } & \text { Jawa } \\
\text { Barat } & \end{array}$ \\
\hline 2 & $\begin{array}{l}\text { Kamis, } 29 \\
\text { Maret } 2018\end{array}$ & Ibu Nina & 45 tahun & $\begin{array}{l}\text { Penjual Kalua Kulit } \\
\text { Jeruk }\end{array}$ & - \\
\hline 3 & $\begin{array}{l}\text { Kamis, } 29 \\
\text { Maret } 2018\end{array}$ & Bapak Wawan & 52 Tahun & $\begin{array}{l}\text { Penjual Kalua Kulit } \\
\text { Jeruk }\end{array}$ & - \\
\hline 4 & $\begin{array}{l}\text { Kamis, } 29 \\
\text { Maret } 2018\end{array}$ & Ibu Anis & 41 Tahun & $\begin{array}{l}\text { Penjual Kalua Kulit } \\
\text { Jeruk }\end{array}$ & - \\
\hline
\end{tabular}




\begin{tabular}{|c|c|c|c|c|c|}
\hline No & Hari/Tanggal & $\begin{array}{c}\text { Nama } \\
\text { Lengkap }\end{array}$ & Usia & Pekerjaan & $\begin{array}{l}\text { Lembaga/ } \\
\text { Instansi }\end{array}$ \\
\hline 5 & $\begin{array}{l}\text { Kamis, } 29 \\
\text { Maret } 2018\end{array}$ & Ibu Fitri & 25 Tahun & $\begin{array}{l}\text { Penjual Kalua Kulit } \\
\text { Jeruk }\end{array}$ & - \\
\hline 6 & $\begin{array}{l}\text { Kamis, } 12 \\
\text { April } 2018\end{array}$ & $\begin{array}{ll}\text { E. } & \text { Tedi } \\
\text { Supriadi } & \end{array}$ & 49 Tahun & $\begin{array}{l}\text { Pegawai Negri Sipil } \\
\text { dan Ahli Gastronomi }\end{array}$ & $\begin{array}{l}\text { Dinas Perindustrian dan } \\
\text { Perdagangan Kabupaten } \\
\text { Bandung }\end{array}$ \\
\hline 7 & $\begin{array}{l}\text { Kamis, } 12 \\
\text { April } 2018\end{array}$ & $\begin{array}{l}\text { Maya Kusuma } \\
\text { Dewi }\end{array}$ & 36 Tahun & Pegawai Negri Sipil & $\begin{array}{l}\text { Dinas Perdagangan dan } \\
\text { Perindustrian Kabupaten } \\
\text { Bandung }\end{array}$ \\
\hline
\end{tabular}

Sumber : Data diolah oleh penulis 2018

\subsection{Pembahasan}

Pembahasan disini merupakan bahasan mengenai hasil penelitian dengan menggunakan pandangan orisinalnya dalam sudut pandang kajian teoritis dan kajian empirik yang terdahulu.

\subsubsection{Sejarah Filosofi dan Tradisi Kudapan Kalua Kulit Jeruk Sebagai Gastronomi Sunda}

Penelitian yang telah dilakukan oleh peneliti dapat dianalisi bahwa terkandung Sejarah, Filosofi dan Tradisi dari kudapan Kalua Kulit Jeruk. Sejarah dari kudapan Kalua kulit jeruk bermula pada tahun 1940, para pertani di Kecamatan Ciwidey yang dahulu masih bernama Kecamatan Pasirjambu sebelum adanya pemekaran, mereka menanan jeruk hasil kawinan antara yang bertujuan untuk mendapatkan buah yang lebih unggul, namun pada saat panen tiba bukan hasil bagus yang didapat melaikan sebaliknya buah yang jadi terasa asam dan pahit serta memiliki daging buah yang kecil serta kulit yang sangat tebal namun keunggulan dari buah hasil persilangan tersebut yaitu tumbuh dengan sangat subur menghasilkan buah yang lebih banyak dari buah yang biasanya ditanam oleh para petani.

Para petani bingung dengan berlimpahnya hasil panen tersebut sedangkan buah tersebut tidak layak untuk dikonsumsi bahkan dijual, akhirnya para petani memiliki ide untuk membuat sebuah produk dari jeruk tersebut dengan berbagai percobaan yang dilakukan akhirnya jadilah sebuah manisan yang terbuat dari kulit jeruk tersebut dan ternyata banyak sekali yang menyukai kudapan tersebut akhirnya pembuatan tersebut turun-menurun dilakukan oleh masyarakat Ciwidey hingga saat ini.

Filosofi dari nama "Kalua" tersebut yaitu. Setelah manisan itu berhasil dibuat dan ternyata banyak masyarakat yang menyukainya, petani disekitar tempat tersebut selalu kebingngan jika ada yang menanyakan produk tersebut karena belum mereka beri nama. Akhirnya terbentuklah nama dari bahasa Sunda yaitu "Kalua" yang memiliki arti Manis, dan kulit jeruk merupakan bahan utamanya jadilah makanan tersebut diberi nama "Kalua Kulit Jeruk" dari sejak itulah Kalua mulai diketahui oleh masyarakat luas dari dulu hingga sekarang.

Sementara tradisi yang berkaitan dengan Kalua kulit jeruk dahulu hanyalah sebagai kudapan pendamping minum the kala sore hari oleh para masyarakat Ciwidey, namun seiring berkembangnya jaman lama-kelamaan Kalua kulit jeruk selalu ada disetiap acara-acara besar yang ada di Ciwidey baik dari perayaan acara perkawinan, kudapan wajib pada saat lebaran datang, serta acara-acara adat lainnya karena Kalua kulit jeruk sudah lekat dengan masyarakat Ciwidey dan sekitarnya.

\subsubsection{Proses Pembuatan Kalua Kulit Jeruk}

Hal-Hal yang Perlu Diperhatikan adalah pemilihan bahan baku jeruk harus yang masih keras dan muda. Saat ini karena sudah susah ditemukan jeruk seperti yang ditanam pada jaman penggantinya adalah jeruk bali yang masih muda karena 
teksturnya hampir mendekati jeruk aslinya.

Selain itu juga beberapa produsen Kalua kulit jeruk yang membuat dengan menggunakan arang atau kayu bakar itu bertujuan agar Kalua yang dihasilkan aromanya lebih wangi dan tidak cepat berair atau lembek.

Air yang digunakan untuk mencuci dan memasak haruslah air yang jernih, jika air yang digunakan keruh atau terlihat agak sedikit kuning maka kalua yang dihasilkan menjadi pahit.

Pencucian kulit jeruk, hal ini harus dilakukan dengan sangat teliti dan berulangulanng sampai rasa pahit dari jeruk tersebut hilang.

Terakhir adalah cuaca, ini sangat berpengaruh karena jika cuaca sedang lembab atau sering hujan kalua yang dihasilkan tidak akan kering jika disimpan di suhu ruangan alhasil kalua akan cepat berjamur dan tidak tahan lama seperti yang biasanya. Daya tahan simpan kalua kulit jeruk akan berkurang.

Terdapat beberapa alat-alat yang biasanya digunakan oleh para produsen untuk membuat Kalua kulit jeruk, diantaranya adalah :

a. Kompor Hawu atau Kompor Gas. Alat ini digunakan untuk memasak Kalua kulit jeruk

b. Pisau. Alat ini digunakan untuk memotong kulit jeruk.

c. Talenan. Alat ini digunakan untuk alas memotong kulit jeruk.

d. Baskom. Alat ini digunakan untuk merendam kulit jeruk.

e. Kolanding. Alat ini digunakan untuk mencuci dan meniriskan kulit jeruk yang sudah direndam.

f. Langseng. Alat ini digunakan untuk merebus kulit jeruk.

g. Katel. Alat ini digunakan untuk memasak kulit jeruk.

h. Cukil. Alat ini digunakan untuk mengocek kulit jeruk.

i. Nyiru/Cecempeh. Alat ini digunakan untuk mendinginkan Kalua kulit jeruk yang baru matang.

j. Keranjang. Alat ini digunakan untuk menyimpan Kalua kulit jeruk yang sudah matang.

Kalua kulit jeruk terbagi dalam dua jenis yaitu Kalua original atau yang biasa disebut Kalua gula aren serta Kalua kulit jeruk biasa atau yang biasa disebut Kalua Warna. Terdapat beberapa bahan yang berbeda dalam cara pembuatannya.

Kalua Kulit Jeruk Original (Kalua Gula Aren) terdiri dari gula aren, kulit jeruk bali, kapur sirih, dan air. sedangkan Kalua Kulit Jeruk Biasa (Kalua Warna) terdiri dari gula pasir, kulit jeruk bali, kapur sirih, air, dan pewarna makanan/essen.

Terdapat perbedaan dalam pembuatan Kalua kulit jeruk original dengan Kalua kulit jeruk warna, perbedaan tersebut akan dijelaskan pada penjelasan dibawah ini :

Cara Pembuatan Kalua Kulit Jeruk Original (Kalua Gula Aren) adalah:

a. Pilih jeruk yang masih muda dan keras, kupas kulit luar jeruk dan ambil bagian daging jeruknya hingga yang tersisa hanya kulit jeruk bagian dalam (berwarna putih).

b. Potong-potong kulit jeruk sesuai dengan selera lalu cuci hingga bersih.

c. Rendam kulit jeruk dalam air yang sudah dicampur dengan kapur sirih, diamkan selama satu malam.

d. Cuci kembali kulit jeruk yang sudah direndam air kapur sirih hingga bersih, tiriskan kulit jeruk mengering.

e. Selagi kulit jeruk ditiriskan, siapkan gula aren dan iris tipis gula aren tersebut agar mudah dicairkan.

f. Panaskan gula aren yang telah diiris ke dalam wajan (Katel) sambil terus diaduk hingga gula mencair. Panaskan harus dengan api kecil agar tidak gosong.

g. Setelah gula aren mencair masukan kulit jeruk dan air, aduk-aduk.

h. Tunggu hingga gula meresap 
kedalam kulit jeruk selama 2-3 jam.

i. Setelah matang simpan kalua dalam nyiru sampai kalua kering dan mengeras. Setelah mengeras simpan dalam keranjang sebelum di display di toko.

Cara Pembuatan Kalua Kulit Jeruk Warna adalah sebagai berikut:

a. Pilih jeruk yang masih muda dan keras, kupas kulit luar jeruk dan ambil bagian daging jeruknya hingga yang tersisa hanya kulit jeruk bagian dalam (berwarna putih).

b. Potong-potong kulit jeruk sesuai dengan selera lalu cuci hingga bersih.

c. Rendam kulit jeruk dalam air yang sudah dicampur dengan kapur sirih, diamkan selama satu malam.

d. Cuci kembali kulit jeruk yang sudah direndam air kapur sirih hingga bersih, tiriskan kulit jeruk mengering.

e. Setelah kulit jeruk mengering, masukan kedalam katel bersamaan dengan gula pasir, air, serta pewarna makanan/essen. Aduk rata dan tunggu hingga air meresap.

f. Setelah matang simpan kalua dalam nyiru sampai kalua kering dan mengeras. Setelah mengeras simpan dalam keranjang sebelum di display di toko.

\subsubsection{Pemasaran Kalua Kulit Jeruk}

Pemasaran dari kudapan kalua kulit jeruk sendiri menurut para produsen saat ini semakin menurun, karena terdapatnya beberapa kendala yang ada seperti banyaknya produk pesaing yang ada di daerah Ciwidey saat ini, bahan baku yang tidak selalu tersedia dan menurunnya minat masyarakat terhadap produk kalua kulit jeruk. Namun masih tetap ada peluang agar produk kalua tetap lestari dan diminati oleh masyarakat yaitu ciri khas bahan baku yang digunakan oleh kudapan ini membuat beberapa masyarakat masih ada saja yang penasaran dan ingin mencobanya, kudapan ini hanya ada di Ciwidey sehingga membuat masyarakat yang berkunjung penasaran dengan ciri khas makanan dari Ciwidey ini.

\subsubsection{Kalua Kulit Jeruk Sebagai Daya Tarik Wisata Gastronomi Sunda di Ciwidey Jawa Barat}

Kalua kulit jeruk memiliki keunikan dari bahan dasar yang digunakannya yaitu kulit jeruk yang tidak lazim digunakan sebagai bahan dasar suatu makanan, sehingga banyak masyarakat yang penasaran ingin mengkonsumsinya serta produk yang hanya bisa didapat di daerah Ciwidey dan sekitarnya. Selama ini pemasaran Kalua kulit jeruk memang hanya dilakukan di wilayah Ciwidey dan sekitarnya, hal ini disebabkan karena para produsen hanya ingin Kalua kulit jeruk bisa ditemukan di daerah Ciwidey saja. Selain itu yang memiliki keterampilan untuk membuat Kalua kulit jeruk hanya masyarakat sekitar Ciwidey saja. Karena hal inilah Kalua kulit jeruk sangat berpeluang untuk dijadikan Daya Tarik Wisata dengan cara melihat proses pembuatannya langsung ke tempat produsen Kalua kulit jeruk.

Berikut adalah paket wisata gastronomi di Kabupaten Bandung yang objeknya adalah Kalua Kulit Jeruk yang sudah dibuat oleh penulis:

Wisatawan dapat mengunjungi tempat proses pembuatan Kalua Kulit Jeruk dan tempat wisata lainnya sebagai pelengkap, dengan Rundown kegiatan adalah sebagai berikut : 
Tabel 5. Rundown Kegiatan Wisata Gastronomi Sunda Kalua Kulit Jeruk

\begin{tabular}{|c|c|c|c|c|}
\hline No & Waktu & Lokasi & Kegiatan & Keterangan \\
\hline 1. & 09.00 & $\begin{array}{l}\text { Tempat Parkir } \\
\text { Tempat Produsen } \\
\text { Kalua Kulit Jeruk } \\
\text { (Jl.Raya Kampung } \\
\text { Warug, Ciwidey) }\end{array}$ & Turun dari kendaraan & $\begin{array}{l}\text { Sampai di tempat parkir } \\
\text { berjalan menuju rumah } \\
\text { produksi. }\end{array}$ \\
\hline 2. & 09.10-09.30 & $\begin{array}{l}\text { Tempat produksi } \\
\text { Kalua Kulit Jeruk }\end{array}$ & $\begin{array}{l}\text { Pengenalan dan } \\
\text { penjelasan mengenai } \\
\text { Kalua Kulit Jeruk }\end{array}$ & $\begin{array}{l}\text { Wisatawan diberi edukasi } \\
\text { mengenai Sejarah Kalua } \\
\text { Kulit Jeruk }\end{array}$ \\
\hline 3. & $09.30-10.00$ & $\begin{array}{l}\text { Tempat Produksi } \\
\text { Kalua Kulit Jeuk }\end{array}$ & $\begin{array}{l}\text { Melihat alat serta bahan } \\
\text { yang digunakan untuk } \\
\text { pembuatan Kalua Kulit } \\
\text { Jeruk }\end{array}$ & $\begin{array}{l}\text { Wisatawan melihat dan } \\
\text { mengetahui langsung alat } \\
\text { serta bahan yang } \\
\text { digunakan } \\
\text { pembuatan Kalua Kulit } \\
\text { Jeruk }\end{array}$ \\
\hline 4 & $10.00-10.30$ & $\begin{array}{l}\text { Tempat Produksi } \\
\text { Kalua Kulit Jeruk }\end{array}$ & $\begin{array}{l}\text { Memilih jeruk yang baik } \\
\text { untuk dibuat Kalua Kulit } \\
\text { Jeruk }\end{array}$ & $\begin{array}{l}\text { Wisatawan diajak } \\
\text { langsung untuk memilih } \\
\text { jeruk yang baik untuk } \\
\text { dibuat Kalua Kulit Jeruk }\end{array}$ \\
\hline 5 & $10.30-10.45$ & $\begin{array}{l}\text { Tempat Produksi } \\
\text { Kalua Kulit Jeruk }\end{array}$ & Pemotongan Kulit jeruk & $\begin{array}{l}\text { Wisatawan diajak } \\
\text { langsung memotong kulit } \\
\text { jeruk }\end{array}$ \\
\hline 6 & $10.45-11.00$ & $\begin{array}{l}\text { Tempat produksi } \\
\text { kalua kulit jeruk }\end{array}$ & Pembersihan kulit jeruk & $\begin{array}{l}\text { Wisatawan diajak } \\
\text { langsung mencuci kulit } \\
\text { jeruk yang baik dan benar }\end{array}$ \\
\hline 7 & $11.00-12.00$ & $\begin{array}{l}\text { Tempat produksi } \\
\text { kalua kulit jeruk }\end{array}$ & $\begin{array}{l}\text { Pemasakan kalua kulit } \\
\text { jeruk }\end{array}$ & $\begin{array}{l}\text { Wisatawan diajak } \\
\text { langsung membuat kalua } \\
\text { kulit jeruk dari awal } \\
\text { prosesnya hingga akhir. }\end{array}$ \\
\hline 8 & $12.00-12.15$ & $\begin{array}{l}\text { Tempat produsen } \\
\text { kalua kulit jeruk }\end{array}$ & $\begin{array}{l}\text { Pemberian Oleh-oleh } \\
\text { Kalua Kulit Jeruk }\end{array}$ & $\begin{array}{l}\text { Kalua yang sudah dibuat } \\
\text { oleh wisatawan dapat } \\
\text { dibawa pulang }\end{array}$ \\
\hline 9. & $12.15-12.25$ & $\begin{array}{l}\text { Tempat produsen } \\
\text { kalua kulit jeruk }\end{array}$ & Sesi Foto & $\begin{array}{l}\text { Wisatawan melakukan } \\
\text { sesi foto dengan } \\
\text { produsen dan peserta } \\
\text { lainnya kalua kulit jeruk } \\
\text { dan produk Kalua kulit } \\
\text { jeruk }\end{array}$ \\
\hline 10. & $12.25-12.35$ & $\begin{array}{l}\text { Menuju ke Tempat } \\
\text { Istirahat }\end{array}$ & & $\begin{array}{l}\text { Wisatawan menuju ke } \\
\text { tempat makan Rumah } \\
\text { Nene }\end{array}$ \\
\hline 11. & $12.35-13.30$ & $\begin{array}{l}\text { Tempat Makan } \\
\text { Rumah Nene }\end{array}$ & ISOMA & $\begin{array}{l}\text { Makan siang dengan nasi } \\
\text { liwet komplit ( nasi liwet, } \\
\text { ayam goreng, ikan asin, } \\
\text { tahu, tempe, sambal, } \\
\text { lalap, dan sayur asem) }\end{array}$ \\
\hline 12. & $13.30-14.00$ & $\begin{array}{l}\text { Tempat Parkir } \\
\text { Rumah Nene }\end{array}$ & Berkumpul dan Persiapan & $\begin{array}{l}\text { Wisatawan berkumpul } \\
\text { dan berangkat meuju } \\
\text { destinasi selanjutnya }\end{array}$ \\
\hline 13. & $14.00-17.00$ & $\begin{array}{l}\text { Tempat Parkir } \\
\text { Glamping Lake Side }\end{array}$ & Acara Bebas & $\begin{array}{l}\text { Wisatawan diberi tiket } \\
\text { untuk menaiki perahu dan } \\
\text { bebas berkegiatan di } \\
\text { tempat wisata Glamping } \\
\text { Lake Side. }\end{array}$ \\
\hline 14. & 17.00 & $\begin{array}{l}\text { Tempat parkir } \\
\text { Glamping Lake Side }\end{array}$ & Pulang & $\begin{array}{l}\text { Wisatawan selesai } \\
\text { mengikuti acara Wisata } \\
\text { Gastronomi Sunda Kalua }\end{array}$ \\
\hline
\end{tabular}




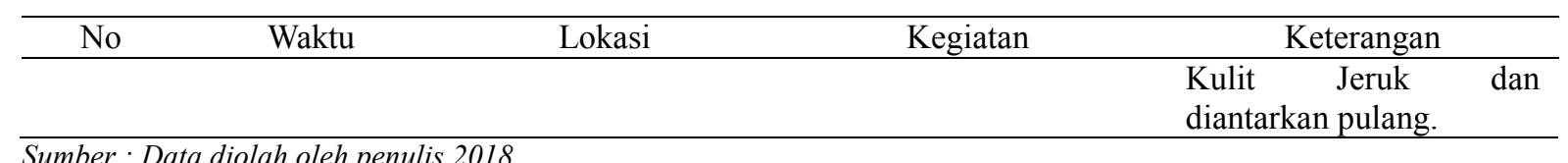

Sumber : Data diolah oleh penulis 2018

Pada Tabel 5 terdapat kolom waktu,lokasi, kegiatan serta keterangan. Untuk kolom waktu menunjukan dimulainya acara, serta berapa lama rentan acara yang berlangsung dalam kegiatan bersama para wisatawan. Kemudian kolom lokasi menunjukan tempat dimana berlangsungnya acara tersebut bersama para wisatawan. Lalu kolom kegiatan menerangkan bagaimana kegiatan berlangsung dan ditambah penjelasan pelengkap pada kolom keterangan.

Segmen atau target pasar dari paket wisata ini secara khusus menyasar kepada para pelajar SMP ataupun SMA yang masih mempelajari tentang kebudayaan Sunda serta para Mahasiswa yang bergelut dibidang kuliner, agar dapat mengetahui sejarah dari suatu makanan bukan hanya diajarkan bagaimana cara membuatnya saja, dan secara umum paket wisata ini juga dapat dinikmati oleh beragam kalangan.

Dengan dibuatnya paket wisata Gastronomi Sunda tersebut diharapkan kudapan Kalua Kulit Jeruk dapat semakin dikenal oleh para wisatawan yang mengungi Ciwidey bahkan oleh masyarakat secara luas. Serta membuat industri kudapan kalua kulit jeruk bangkit kembali seperti dahulu dan bisa meningkatkan pendapatan para produsen Kalua Kulit Jeruk.

Tabel selanjutnya menerangkan rincian biaya yang dibutuhkan untuk mengikuti kegiatan Wisata Gastronomi.

Tabel 5. Rician Biaya Paket Wisata Gastronomi

\begin{tabular}{lll}
\hline No & \multicolumn{1}{c}{ Keterangan } & Harga (Rp) \\
\hline 1 & Transportasi & 50.000 \\
2 & Makan Siang & 35.000 \\
3 & Tiket Masuk Pabrik Kalua & 20.000 \\
4 & Tiket Masuk Glamping & 20.000 \\
& Lakeside & 25.000 \\
5 & Tiket Perahu & Rp. 150.000 \\
& Jumlah
\end{tabular}

Biaya total yang dibutuhkan oleh wisatawan sebesar Rp 150.000/orang, biaya tersebut termasuk transportasi, makan siang, tiket masuk pabrik kalua, tiket masuk glamping lake side, dan tiket menaiki perahu di glamping. Selain itu wisatawan juga mendapatkan gratis oleh-oleh kalua kulit jeruk dari parbiknya langsung.

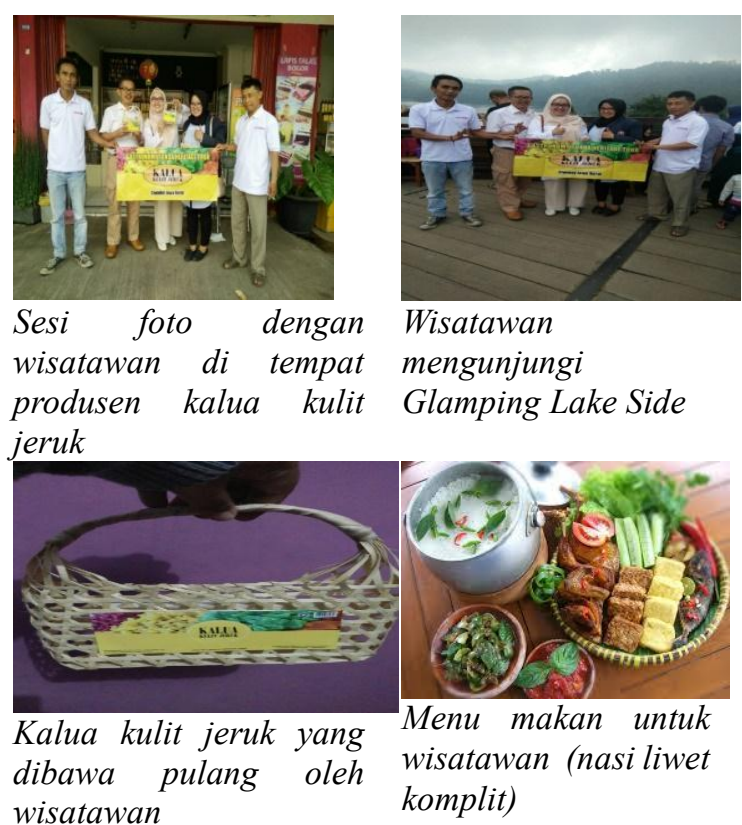

Gambar 3. Dokumentasi Wisata Gastronomi Sunda

Gambar 3 merupakan Wisata Gastronomi Sunda yang telah dilaksanakan pada Kamis, 10 Mei 2018, wisatawan diajak berkeliling pabrik dan melihat langusng Kalua Kulit Jeruk dipasarkan dan dijelaskan bagaimana proses membuatnya, setelah itu wisatawan juga diajak ke Glamping Lake Side untuk menikmati fasilitas yang ada disana tak lupa wisatawan juga diberi makan liwet kumplit yang sudah termasuk dalam paket, bonusnya adalah wisatawan bisa membawa pulang Kalua Kulit Jeruk yang sudah diinovasi kemasannya.

Pendapat yang disampaikan oleh para wisatawan, adalah mereka senang bisa melakukan wisata yang berbeda dari biasanya, Ciwidey menawarkan wisata baru yang unik serta memberi wawasan bukan 
hanya sekedar bersenang senang. Karena wisatawan yang melakukan tour Wisata Gastronomi ini adalah guru kemungkinan wisata ini akan diterapkan kedepannya dengan mengajak serta para sisawanya belajar langsung melestarikan salah satu Gastronomi Sunda dengan cara dan penyampaian yang menarik.

Tantangan atau kendala yang dialami dalam pembuatan paket wisata ini adalah karena belum gencarnya promosi yang dilakukan makan penulis masih kesulitan dalam mencari konsumen yang mau berwisata, lalu tempat produksi kalua yang tidak memproduksi setiap harinya membuat jadwal wisata harus dipersiapkan dengan matang agar para saat wisata berlangsung tempat produksi harus sedang berproduksi, jarak yang jauh dengan perkotaan membuat biaya transportasi menjadi lebih mahal dengan biaya lainnya, serta kemacetan yang sulit dihindari jika tour diadakan pada saat hari libur bisa mengurangi kenyamanan para wisatawan.

Diadakannya tour tersebut penulis bisa mengetahui beberapa kelemahan dan apa saja kekurangan dari paket wisata tersebut, untuk itu penulis melakukan beberapa perbaikan dalam paket wisata tersebut agar paket wisata ini selain bisa memberikan kepuasan bagi para konsumennya, paket wisata ini juga bisa menjadi bisnis yang layak untuk kedepannya.

Paket wisata "Gastronomi Haritage Tour" minimal dilakukan oleh 10 orang atau 10pax hal ini dilakukan karena jika tour dilaksanakan oleh kurang dari 10pax tidak ada keuntungan yang bisa diambil dalam segi bisnis akan merugi, hal ini dipertimbangkan karena biaya transportasi yang akan membengkak bila semakin sedikit wisatawan yang mengikuti tour.

\subsubsection{Upaya Pelestarian Kudapan Kalua Kulit Jeruk Gastonomi Sunda}

Sebagai generasi muda penerus bangsa kita patutu berbangga dengan adanya gastronomi sunda yang sudah kita miliki, dan sepatutnya kita harus terus menjaga serta melestarikannya dengan berbagai cara masing-masing. Begitupun dengan kudapan Kalua Kulit Jeruk Gastronomi Sunda yang harus terus dilestarikan agara keberadaannya tidak punah tergerus zaman.

Upaya pelestarian kudapan Kalua Kulit Jeruk dari berbagai pihak telah dilakukan. Beberapa pihak yang terlibat dalam melestarikan kudapan tersebut adalah pemerintah Kabupaten Bandung, Produsen Kalua Kulit Jeruk, serta pihak lainnya.

Pemerintah daerah Kabupaten Bandung telah melakukan beberapa upaya untuk melestarikan kudapan tersebut, salah satunya ialah membuat berbagai acara yang bertemakan Makanan Tradisional Khas Kabupaten Bandung, mempromosikan Kudapan Kalua Kulit Jeruk sebagai buah tangan ke berbagai daerah lainnya yang dikunjungi oleh pihak pemerintah, memberikan berbagai bantuan untuk membangkitkan industri Kalua kulit jeruk.

Selain pihak pemerintah, produsen Kalua kulit jeruk sendiri melakukan berbagai cara untuk melestarikan kudapan tersebut agar tetap eksis dan dapat bersaing dengan kudapan lainnya yang ada di Ciwidey, hal yang dilakukan tersebut yaitu menurunkan usaha yang mereka miliki kepada generasi penerusnya serta melakukan promosi dengan mengikuti acara-acara yang diselenggarakan oleh pihak pemerintah maupun pihak swasta serta terus memasarkan kudapan kalua yang dibuat meskipun banyak kendala yang dialami oleh para produsen saat ini, diantaranya adalah bermunculannya produk-produk yang lebih menarik yang diinovasi oleh para UKM yang ada di Ciwidey Jawa Barat, ketahanan pangan dari produk lain yang bisa bertahan lama dari kudapan Kalua kulit jeruk serta kurangnnya pengetahuan dari masyarakat atau wisatawan yang datang mengenai kudapan ini sehingga mereka tidak begitu ingin tahu tentang kudapan Kalua kulit jeruk. Namun selain kendala ada pula peluang dari penjualan kudapan ini yaitu keunikan dari 
bahan baku yang membuat orang penasaran dan kudapan ini hanya terdapat di Ciwidey.

Upaya pelestarian juga dilakukan oleh pihak lainnya yaitu para ahli gastronomi dan pelestari makanan yang beberapakali menyelenggarakan berbagai acara untuk mengenalkan kudapan tradisional Sunda, acara yang baru saja digelar yaitu "Pasar Buhun" yang digelar pada Sabtu, 21 April 2018 bertempat di Zie Café Jl. Van Deventer . Acara ini melibatkan berbagai pihak seperti para Ahli Gastronoimi, Dosen bidang kuliner, Mahasiswa Pelestari makanan tradisional, Seniman Sunda serta Kelompok masyarakat pembuat makanan tradisional Sunda.

Rangkaian acara yang terdapat pada "Pasar Buhun" ini antara lain : pameran produk gastronomi sunda seperti Kalua Kulit Jeruk, Angleng, Dapros, Borondong, Ciwang, Ulen, Kurupuk Banjur dan berbagai macam makanan lainnya. Selain itu juga ada demo masak Angleng dan Dapros oleh ibu-ibu pelestari makanan sunda, dan demo masak Kadedemes dan Daging yang diolah dengan proses pemasakan tradisional oleh chef-chef handal pelestari Gastronomi Sunda, serta berbagai hiburan dari para seniman Sunda.

Salah satu upaya penulis dalam melestarikan kudapan Kalua kulit jeruk adalah:

a. Menjadikan kudapan Kalua kulit jeruk sebagai daya tarik wisata gastronomi sunda di Ciwidey jawa barat dengan membuatkan paket wisata yang sudah tertera.

b. Membuat kemasan Kalua Kulit Jeruk yang sudah disesuaikan dengan kebutuhan produknya. Produk Kalua memiliki berbagai kelemahan jika disimpan di tempat yang tertutup, maka penulis membuat kemasan yang sesuai yaitu dengan membuat kemasan yang tidak terlalu tertutup dan pelastik yang digunakan pun diberi rongga udara agar kalua tidak cepat basah bila disimpan terlalu lama dalam kemasan. Daya tahan simpan kalua sendiri bilang tidak dalam kemasan bisa tahan hingga 1bulan namun jika dalam kenasan yang sudah dibuat kudapan kalua kulit jeruk ini hanya bertahan hingga 2 minggu tergantung dari penyimpanan kemasan itu sendiri, semakin kemasan disimpan di tempat yang kering makan kalua yang terdapat di dalamnya akan semaikn awet.

c. Mempromosikan Kalua dengan berbagai macam cara seperti mengikuti berbagai acara Kuliner Tradisional yang diselenggarakan oleh berbagai macam pihak contoh, berpartisipasi dalam acara "Pasar Buhun"

Selain mempromosikan dengan menjual Kalua Kulit Jeruk pada Masyarakat penulis juga mencoba mengedukasi masyarakat agar tidak takut untuk memakan Kalua Kulit Jeruk yang rasanya manis, Karena bahan yang digunakan merupakan bahan yang alami dan aman untuk dikonsumsi, manfaat mengkonsumsi Kalua Kulit Jeruk terutama yang Gula Aren bisa menambah energi bagi masyarakat yang sangat padat aktifitas dan tidak memiliki cukup waktu untuk mengkonsumsi makanan yang beragam kalua merupakan solusi yang tep

\section{Kesimpulan}

Berdasarkan penelitian yang telah dilakukan dengan judul "pelestarian" Kudapan Kalua Kulit Jeruk sebagai Gastronomi Sunda di Ciwidey Jawa Barat" maka dapat disimpulkan bahwa

Kalua sudah ada sejak tahun 1940 dibuat pertama kali oleh petani asal Ciwidey, Jawa Barat. Dalam bahasa Sunda "kalua" memiliki arti manis jadilah dinamakan kalua kulit jeruk atau manisan kulit jeruk. Tradisi yang berkaitan dengan kudapan kalua kulit jeruk dahulu disantap sebagai pendamping minum teh kala sore hari dan selalu ada dalam acara-acara besar seperti lebaran, pernikahan dan acara lainnya.

Proses pembuatan Kudapan Kalua Kulit Jeruk tidaklah sulit, hanya ada 
beberapa cara yang harus diperhatikan agar kudapan yang dihasilkan berkualitas baik. Bahan- bahan yang digunakanpu mudah ditemui dipasaran.

Salah satu upaya penulis dalam melestarikan kudapan kalua kulit jeruk yaitu dengan membuat paket wisata "Gastronomi Heritage Tour" yang diharapkan tour ini menjadi salah satu daya tarik wisata pilihan masyarakat. Serta pembuatan kemasan kalua kulit jeruk agar kudapan tersebut bisa lebih menarik dan semakin banyak diminati.

Bagian ini merupakan penutup artikel. Simpulan ditulis tanpa nomor, dan disajikan dalam bentuk paragraf. Implikasi dan keterbatasan penelitian juga disajikan dalam bentuk paragraf.

\section{Daftar Pustaka}

Alawasilah, A. Chaedar. 2006 Pokoknya Sunda Interpretasi Untuk Aksi. Bandung: Kiblat

A.W. Widjaja. 2016. Pelestarian Budaya Sunda. Bandung: Ranjabar

Haryono, Timbul. 2013. Berbagai Makanan dan Minuman Masyarakat Jawa Kuna. Yogyakarta.Borobudur Writer Festival

Muaris, H. 2004. Makanan Sehat dan Lezat di Masa Menoupouse KUDAPAN. Jakarta: PT.Gramedia Pustaka Utama

Prendit, S. Nyoman. 2003. Ilmu Pariwisata Sebuah Pengantar Perdana. Jakarta: PT.Pradnya Paramita.

Prendit, S. Nyoman. 2006. Ilmu Pariwisata Sebuah Pengantar Perdana. Jakarta: PT.Percetakan. Penebar Swadaya.

Spillane, James J. 2002. Ekonomi Pariwisata Sejarah dan Prospeknya. Yogyakarta:Kamisius

Suwantoro. 2004. Dasar-Dasar Pariwisata.Yogyakarta:ANDI

Sugiono. 2016. Metode Penelitian Pendidikan. Bandung: PT. Alfabeta

Taqwani, M.D. 2012. A-reseaerch.upi.edu. Analisis Kebudayaan Gastronomi dan Tindak Tutur dalam Kajian Pragmatik pada Film Ratatoulie,55

Turgarini, Dewi. 2014. Kekuatan Makanan dan Minuman Tradisional Sebagai

Atraksi Wisata. Bandung. 